\title{
Anestesia para Correção Cirúrgica de Blalock-Taussig e Implante de Marca-Passo em Adulto Portador de Ventrículo Único. Relato de Caso*
}

\author{
Anesthesia for Blalock-Taussig Shunt and Pacemaker Placement \\ in an Adult Patient with Univentricular Heart. Case Report
}

\author{
Michelle Nacur Lorentz, TSA ${ }^{1}$, Raquel Reis Soares, TSA ${ }^{1}$, Cláudia Vargas Araújo Ribeiro², Friederike Wolff Valadares ${ }^{1}$
}

\section{RESUMO}

Lorentz MN, Soares RR, Ribeiro CVA, Valadares FW - Anestesia para Correção Cirúrgica de Blalock-Taussig e Implante de Marca-Passo em Adulto Portador de Ventrículo Único. Relato de Caso.

JUSTIFICATIVA E OBJETIVOS: O ventrículo único é uma cardiopatia complexa rara e grave, sem possibilidade de tratamento cirúrgico curativo, associada à alta mortalidade durante a primeira infância. O objetivo desse artigo foi descrever um caso raro de paciente adulto com ventrículo único não-operado que se internou para realização de valvoplastia pulmonar via hemodinâmica e acabou sendo submetido à cirurgia de Blalock-Taussig modificado e implante de marca-passo epicárdico. Teve como objetivo complementar chamar a atenção para as particularidades anestésicas do paciente adulto portador de cardiopatia congênita não-corrigida.

RELATO DO CASO: Paciente de 34 anos, $60 \mathrm{~kg}$, portadora de cardiopatia congênita complexa tipo ventrículo único, estenose infundibulovalvar pulmonar importante e hipertensão pulmonar moderada. Admitida no hospital sem condições de correção cirúrgica e com história pregressa de várias sangrias terapêuticas para tratamento de policitemia. Foi internada devido a piora da hipoxemia, um episódio de síncope e bloqueio atrioventricular total (BAVT) de início recente. À internação apresentava estabilidade hemodinâmica, freqüência cardíaca de 42 bpm, $\mathrm{SpO}_{2}$ de $73 \%$, cianose central e de extremidades e pressão arterial de $120 \times 70$ $\mathrm{mmHg}$. Foi proposta a realização de cateterismo e valvoplastia pulmonar via hemodinâmica. Por causa da impossibilidade de realização dessa técnica com sucesso, foi indicada a realização de cirurgia de Blalock-Taussig com implante de marca-passo. O procedimento foi realizado no dia seguinte sem intercorrências e a paciente teve alta hospitalar sete dias após o procedimento cirúrgico com $\mathrm{SpO}_{2}$ de $85 \%$, hematócrito de $49 \%$ e melhora da dispnéia.

${ }^{*}$ Recebido do (Received from) Hospital Biocor, Nova Lima, MG

1. Anestesiologista do Hospital Biocor

2. Anestesiologista do Hospital Biocor e Santa Casa de Misericórdia de Belo Horizonte

Apresentado (Submitted) em 28 de março de 2007

Aceito (Accepted) para publicação em 19 de fevereiro de 2008

Endereço para correspondência (Correspondence to):

Dra. Michelle Nacur Lorentz

Rua Marquês de Maricá, 181/1502 — Santo Antônio

30350-070 Belo Horizonte, MG

E-mail:mnacur@yahoo.com.br

(C) Sociedade Brasileira de Anestesiologia, 2008
CONCLUSÕES: O sucesso do procedimento anestésico para correção cirúrgica de cardiopatia congênita complexa demanda conhecimento da fisiopatologia da doença, bem como das particularidades inerentes à técnica anestésica utilizada.

Unitermos: CIRURGIA, Cardíaca: Blalock-Taussig, implante de marca-passo; DOENÇAS, Congênita: ventrículo único.

\section{SUMMARY}

Lorentz MN, Soares RR, Ribeiro CVA, Valadares FW - Anesthesia for Blalock-Taussig Shunt and Pacemaker Placement in an Adult Patient with Univentricular Heart. Case Report.

BACKGROUND AND OBJECTIVES: Univentricular heart is a complex, rare, and severe cardiopathy, with no possibility of curative surgical treatment, associated with a high mortality in the first years of life. The objective of this article was to describe a rare case of an adult patient with uncorrected single ventricle who was admitted for pulmonary valvuloplasty but was submitted to a modified Blalock-Taussig and placement of an epicardic pacemaker. The complementary objective of this report was to address the anesthetic particularities of adult patients with uncorrected congenital cardiopathy.

CASE REPORT: A 34 years old female patient, weighing $60 \mathrm{~kg}$, with a complex congenital cardiopathy with a single ventricle, important infundibular pulmonary stenosis and moderate pulmonary hypertension was admitted to the hospital without conditions to undergo surgical correction. The patient had a history several therapeutic bleedings to treat polycythemia. She was admitted due to worsening hypoxemia, an episode of syncope, and recent onset of third degree atrioventricular block. On admission, the patient was hemodynamically stable, heart rate of $42 \mathrm{bpm}, \mathrm{SpO}_{2} 73 \%$, central cyanosis and cyanosis of the extremities, and blood pressure 120 $\times 70 \mathrm{mmHg}$. Cardiac catheterization and pulmonary valvuloplasty were proposed. Due to the impossibility of success of this technique, Blalock-Taussig procedure with placement of a pacemaker was indicated. The procedure was performed in the following day without intercurrences, and the patient was discharged 7 days after the surgery, with $\mathrm{SpO}_{2} 85 \%$, hematocrit $49 \%$, and improvement of the dyspnea.

CONCLUSIONS: The success of anesthesia for surgical correction of complex congenital cardiopathy requires knowledge on the pathophysiology of the disorder, as well as the particularities inherent to the anesthetic technique used.

Key Words: DISEASES, congenital: single ventricle; SURGERY, Cardiac: Blalock-Taussig, pacemaker placement. 


\section{INTRODUÇÃO}

Uma ampla variedade de defeitos cardíacos compartilha características comuns que funcionam, sob o aspecto fisiológico, como uma única câmara ventricular e são classificados como "ventrículo único". Esses defeitos incluem atresia tricúspide com ventrículo único direito ou esquerdo, dupla via de saída do ventrículo direito com defeito do septo ventricular discordante e a síndrome de hipoplasia do coração esquerdo. Do ponto de vista anatômico esses defeitos são bem diversos, mas funcionalmente se comportam como ventrículo único, sendo cardiopatias complexas muito graves, com alta mortalidade no primeiro ano de vida. Em torno de $50 \%$ dos pacientes morrem até quatro anos após o diagnóstico e, posteriormente, a mortalidade é de $4,8 \%$ ao ano. Restaino e col. descreveram um caso de ventrículo único tipo esquerdo em mulher de 57 anos que não havia se submetido a correção cirúrgica. Até então, apenas 10 casos de ventrículo único não-corrigidos haviam sido encontrados na literatura com sobrevida superior aos 50 anos ${ }^{1}$. Esses casos mostraram a rara ocorrência de compensação espontânea. No estudo de pacientes adultos com ventrículo único não-corrigido, observou-se que a combinação de dupla via de entrada do ventrículo esquerdo com transposição das grandes artérias e estenose pulmonar moderada ou grau moderado de hipertensão pulmonar permitiria, em alguns casos, um equilíbrio adequado das circulações sistêmica e pulmonar, favorecendo a oxigenação sangüínea adequada a vida adulta. A correção cirúrgica desses pacientes é bastante difícil, sendo realizadas apenas operações paliativas ou transplante cardíaco. Essa reparação dos ventrículos exige anatomia extremamente favorável, o que em geral não ocorre, embora fosse o caso no paciente descrito por Ebert ${ }^{2}$. Quando há fluxo sangüíneo inadequado para o pulmão recorre-se a procedimentos cirúrgicos paliativos com shunt sistêmico-pulmonar como medida para melhorar a oxigenação. Dentre esses procedimentos podese utilizar principalmente o de Blalock-Taussig modificado (anastomose subclávio-pulmonar) ou o de Fontan (anastomose cavo-pulmonar). $\mathrm{O}$ objetivo desse artigo foi relatar um caso que, além de raro, apresentou a particularidade de ter que submeter uma paciente com hipertensão pulmonar (HP) à correção cirúrgica de Blalock-Taussig.

\section{RELATO DO CASO}

Paciente de 34 anos, sexo feminino, $60 \mathrm{~kg}, 1,64 \mathrm{~m}$, portadora de cardiopatia congênita cianogênica complexa (ventrículo único tipo esquerdo, associado à estenose infundibulovalvar pulmonar importante e hipertensão pulmonar moderada). Havia apresentado recentemente síncope e bloqueio atrioventricular total, mantendo freqüência cardíaca (FC) de $42 \mathrm{bpm}$ e pressão arterial (PA) de $120 \times 70 \mathrm{mmHg}$. Esse quadro foi acompanhado de taquidispnéia e tonturas recorrentes. Internou-se com $\mathrm{SpO}_{2}$ de $73 \%$, hematócrito $(\mathrm{Htc})$ de
$70 \%$, hemoglobina $(\mathrm{Hb})$ de 22,2 g.dL-1 e INR de 2,1. Foi realizado ecocardiograma que confirmou ventrículo único "tipo E" com dupla via de entrada e dupla via de saída, vasos posicionados normalmente e estenose pulmonar moderada a importante; a pressão de artéria pulmonar encontrada foi de $30 \mathrm{mmHg}$. Foi, então, realizada sangria para diminuição da policitemia e da cianose central, hidratação, administração de vitamina $\mathrm{K}$ e disponibilizado marca-passo transcutâneo. A seguir, foi realizado cateterismo cardíaco para tentativa de dilatação da artéria pulmonar esquerda sem sucesso; o procedimento foi feito com anestesia local associada à sedação consciente com midazolam $2 \mathrm{mg}$, fentanil $100 \mu \mathrm{g}$ e oxigênio $\left(\mathrm{O}_{2}\right) 3 \mathrm{~L}$. $\mathrm{min}^{-1}$ por cateter nasal. No dia seguinte a paciente foi encaminhada ao centro cirúrgico para a realização da correção cirúrgica de Blalock-Taussig modificado à direita com prótese de dacron e implante de marca-passo epicárdico. O objetivo do procedimento cirúrgico foi melhorar a oxigenação e diminuir a síndrome de poliglobulia que a paciente apresentava de forma recorrente. A monitoração intra-operatória constou de eletrocardiograma (ECG) contínuo, oxímetro de pulso $\left(\mathrm{SpO}_{2}\right)$, capnógrafo, pressão arterial invasiva em artéria radial esquerda (contralateral o lado do Blalock), temperatura nasofaríngea, sonda vesical de demora e gasometrias seriadas. A técnica anestésica utilizada foi anestesia geral balanceada com sevoflurano a $2 \%$, fentanil, etomidato e atracúrio. Foi administrado $1,5 \mathrm{mg} \cdot \mathrm{kg}^{-1}$ de heparina antes do pinçamento da artéria pulmonar e revertido com $70 \%$ de dose da protamina ao final do procedimento cirúrgico. Foi utilizada $\mathrm{FiO}_{2}$ de 0,5 em mistura com ar por causa da estabilidade hemodinâmica e não houve necessidade do uso de fármacos inotrópicos. Ao final do procedimento a paciente foi extubada e apresentava $\mathrm{SpO}_{2}$ de $95 \%$ que manteve-se em torno de $85 \%$ com o funcionamento do Blalock no pós-operatório imediato. O hemograma da paciente no dia da alta mostrava $\mathrm{Hb}$ de $15,9 \mathrm{~g} \cdot \mathrm{dL}^{-1}$ e Htc de $49 \%$. No seguimento tardio (um ano) após o procedimento cirúrgico a paciente encontrava-se estável, exercendo atividades domésticas e com $\mathrm{SpO}_{2}$ de $83 \%$.

\section{DISCUSSÃO}

Ocorrendo em cerca de 8 casos para cada 1.000 nascidos vivos ${ }^{3}$, os defeitos cardíacos congênitos são a forma mais comum de malformação do ser humano. Os pacientes com ventrículo único de morfologia esquerda e a câmara rudimentar anterior representam $0,7 \%$ das cardiopatias congênitas ${ }^{1}$. Raras vezes esses pacientes chegam à idade adulta sem intervenção paliativa ou corretiva prévia, a não ser que apresentem estenose pulmonar ou discreta a moderada hipertensão pulmonar ${ }^{2}$, pois esses fatores podem regular 0 fluxo sangüíneo pulmonar nesses pacientes, permitindo uma sobrevida maior. A principal causa de falecimento são as disritmias cardíacas (fibrilação atrial) ou a insuficiência cardíaca congestiva ${ }^{4}$. 
No presente caso o BAVT ocorreu em virtude da evolução natural da doença, visto que nesse tipo de cardiopatia a região das valvas e a região do nó sinoatrial costumam ser acometidas levando tardiamente ao BAV. Apesar de a paciente apresentar estenose pulmonar, ela desenvolveu hipertensão pulmonar (HP), provavelmente devido à trombose in situ ou a hipoplasia de ramos da árvore pulmonar. Entretanto, a HP não era grave e o predomínio nessa paciente era de baixo fluxo sangüíneo pulmonar já que o seu quadro clínico era de cianose e hipoxemia extrema. Assim, foi realizada a correção cirúrgica de Blalock-Taussig modificado, pois era necessário aumento de fluxo sangüíneo pulmonar para que a paciente apresentasse melhora da $\mathrm{SpO}_{2}$, pois havia estenose pulmonar valvar importante. Pensou-se, em um primeiro momento, na realização da correção cirúrgica de Glenn (anastomose veia cava superior - artéria pulmonar); entretanto, esse procedimento não deve ser feito em pacientes que apresentem pressão de artéria pulmonar maior que $15 \mathrm{mmHg}$ e, nesse caso, a pressão de pulmonar da paciente era de $30 \mathrm{mmHg}$.

Pacientes com fisiologia de ventrículo único funcionalmente respondem a intervenções comuns como oxigênio suplementar, ventilação mecânica e fármacos vasoativos, de forma diferente dos outros pacientes ${ }^{5,6}$. Quando há anatomia univentricular, as circulações funcionam em paralelo, e tanto a circulação pulmonar quanto a sistêmica são feitas com mistura de sangue oxigenado e sangue não-oxigenado. Saturações arteriais de oxigênio entre $70 \%$ e $80 \%$ são fisiológicas para eles; saturações mais elevadas, que são alcançadas por métodos suplementares, são deletérias para sua fisiologia. Portanto, o manuseio anestésico dos pacientes com circulação em paralelo exige entendimento profundo da fisiopatologia da doença, bem como individualização da técnica anestésica para cada paciente. Em cardiopatias congênitas complexas a escolha dos fármacos anestésicos não é tão importante quanto o conhecimento e adequado manuseio da hemodinâmica do paciente ${ }^{6}$. O sucesso na abordagem desses pacientes costuma demandar manutenção de $\mathrm{SpO}_{2}$ em torno de $75 \%$ e $\mathrm{SvO}_{2}$ em torno de $50 \%$, na tentativa de manter o equilíbrio entre as duas circulações.

A monitoração mais adequada para esses pacientes parece ser a $\mathrm{SvO}_{2}$, pois ela permite conhecer a oferta tecidual de $\mathrm{O}_{2}$ e alguns autores têm indicado que ela seja feita de forma contínua na veia cava superior ${ }^{7}$. A utilização da $\mathrm{P}_{\mathrm{ET}} \mathrm{CO}_{2}$ em pacientes com baixo fluxo sangüíneo pulmonar perde muito a sensibilidade como indicador da pressão arterial de $\mathrm{CO}_{2}\left(\mathrm{PaCO}_{2}\right)$, pois nesses casos o espaço morto é muito grande, aumentando o gradiente $\mathrm{Pa}-\mathrm{P}_{\mathrm{ET}} \mathrm{CO}_{2}$. O principal objetivo da anestesia é a manutenção da relação entre o débito pulmonar e o sistêmico próxima a 1. Isso porque nas circulações em paralelo se houver excesso de fluxo sangüíneo pulmonar ocorrerá diminuição do fluxo sangüíneo sistêmico com baixo débito cardíaco, acidose láctica e disfunção miocárdica ${ }^{8}$. Ao contrário, se houver baixo fluxo san- güíneo pulmonar ocorre hipoxemia importante com comprometimento da vida. Logo, o manuseio desses pacientes baseia-se principalmente na ventilação adequada. $\mathrm{O}$ uso de altas $\mathrm{FiO}_{2}$, hipocapnia e manobras que diminuam a pressão vascular pulmonar devem ser evitados, pois geram vasodilatação pulmonar com altos fluxos sangüíneos pulmonares em detrimento do fluxo sangüíneo sistêmico; por outro lado, a hipoxemia e a hipercapnia geram vasoconstrição pulmonar com desvio do sangue para a circulação sistêmica. Utiliza-se na maioria das vezes $\mathrm{FiO}_{2}$ a 0,5 em mistura com ar, embora alguns casos de pacientes com hiperfluxo pulmonar demandem acréscimo de $\mathrm{CO}_{2}$ ao sistema ventilatório para controle da vasodilatação pulmonar ${ }^{9}$. Durante muito tempo o anestesiologista se orientou nesses casos pela $\mathrm{SpO}_{2}$. Hoje, sabe-se que tanto a $\mathrm{SpO}_{2}$ quanto os parâmetros hemodinâmicos como PA e FC para monitoração intra-operatória desses pacientes são suplantados por marcadores biológicos como $\mathrm{SvO}_{2}$ (saturação do sangue venoso misto) e dosagem do lactato ${ }^{10,11}$. $\mathrm{A} \mathrm{SvO}_{2}$ deve-se manter em torno de $50 \%$ e a dosagem do lactato vale mais pela sua tendência a abaixar ou continuar elevada, do que pelos seus valores absolutos.

A extubação precoce desses pacientes pode ser feita desde que o paciente esteja respirando de forma espontânea e sem risco de reter $\mathrm{CO}_{2}$. Ela pode ser vantajosa em melhorar a hemodinâmica do paciente; entretanto, muitos adultos com cardiopatias congênitas têm a função pulmonar alterada e isso pode ser de relevância na decisão de extubar ou não o paciente precocemente.

\section{Anesthesia for Blalock-Taussig Shunt and Pacemaker Placement in an Adult Patient with Univentricular Heart. Case Report}

Michelle Nacur Lorentz, TSA, M.D.; Raquel Reis Soares, TSA, M.D.; Cláudia Vargas Araújo Ribeiro, M.D.; Friederike Wolff Valadares, M.D.

\section{INTRODUCTION}

A wide variety of cardiac defects share common characteristics that, physiologically, work as a single ventricular chamber and, therefore, are classified as "univentricular". Those defects include tricuspid atresia with a single right or left ventricle, double outlet right ventricle with noncommitted ventricular septal defect, and syndrome of left heart hypoplasia. Anatomically, those defects are very diverse, but functionally they behave as a single ventricle and are extremely severe complex cardiopathies, with a high mortality rate in the first year of life. Approximately $50 \%$ of the patients are dead 4 years after the diagnosis and, afterwards, it has a 
mortality rate of $4.8 \%$ per year. Restaino et al. described a case of single left ventricle in a 57-year old female who had not had corrective cardiac surgery; until that moment, only 10 cases of non-corrected single left ventricle who survived past age 50 had been reported in the literature ${ }^{1}$. Those cases demonstrate the rare occurrence of spontaneous compensation. In the study of patients with uncorrected single left ventricle, it was observed that the combination of double left ventricular inlet with transposition of the great vessels and moderate pulmonary stenosis or moderate pulmonary hypertension would allow, in some cases, an adequate balance between the systemic and pulmonary circulations, favoring blood oxygenation adequate for adult life. Surgical repair in those individuals is very difficult; therefore, only palliative surgeries are done or heart transplant. Repair of the ventricles requires an extremely favorable anatomy, which is not commonly found, although this was the case of the patient described by Ebert ${ }^{2}$. When the blood flow for the lungs is inadequate, palliative surgeries, with systemic-pulmonary shunt, are done to improve oxygenation. Among those procedures, one can use especially the modified Blalock-Taussig (subclavian-pulmonary anastomosis) or Fontan (cava-pulmonary anastomosis) procedure. The objective of this article was to report a case that, besides being rare, presented the particularity of having to submit a patient with pulmonary hypertension $(\mathrm{PH})$ to Blalock-Taussig surgical correction.

\section{CASE REPOT}

A 34 years old female patient, weighing $60 \mathrm{~kg}, 1.64 \mathrm{~m}$, with complex cyanotic congenital cardiopathy (single ventricle associated with severe infundibular pulmonary stenosis and moderate pulmonary hypertension). Recently, she had experienced one episode of syncope and developed third degree AV block, maintaining a heart rate (HR) of $42 \mathrm{bpm}$ and blood pressure (BP) of $120 \times 70 \mathrm{mmHg}$. This was accompanied by tachydyspnea and recurring dizziness. On admission, she presented $\mathrm{SpO}_{2} 73 \%$, hematocrit $(\mathrm{Ht}) 70 \%$, hemoglobin

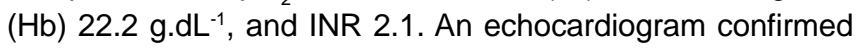
"type E" single ventricle with double intlet and outlet, normally positioned vessels, and moderate to severe pulmonary stenosis; pressure in the pulmonary artery was $30 \mathrm{mmHg}$. Bleeding was performed to reduce polycythemia and central cyanosis, the patient was hydrated, vitamin $\mathrm{K}$ was administered, and a subcutaneous pacemaker was available. Cardiac catheterization was, then, performed in an attempt to dilate the left pulmonary artery, which was unsuccessful; the procedure was done under local anesthesia associated with conscious sedation with $2 \mathrm{mg}$ of midazolam, $100 \mu \mathrm{g}$ of fentanyl, and oxygen $\left(\mathrm{O}_{2}\right) 3 \mathrm{~L}$. $\mathrm{min}^{-1}$ by nasal catheter.

On the following day, the patient was transferred to the operating room for a surgical repair using the modified BlalockTaussig in the right with Dacron prosthesis and placement of an epicardic pacemaker. The objective of the procedure was to improve oxygenation and decrease the recurring poly- cythemia. Intraoperative monitoring consisted of continuous electrocardiogram (ECG), pulse oximetry $\left(\mathrm{SpO}_{2}\right)$, capnograph, invasive blood pressure on the left radial artery (contralateral to the Blalock), nasopharyngeal temperature, urinary catheter, and serial blood gases. General balanced anesthesia was done with $2 \%$ sevoflurane, fentanyl, etomidate, and atracurium. Heparin, $1.5 \mathrm{mg} \cdot \mathrm{kg}^{-1}$, was administered before clamping the pulmonary artery and, at the end of the surgery, it was reversed with $70 \%$ of the dose of protamine. $\mathrm{A} \mathrm{FiO}_{2}$ of 0.5 mixed with room air was used, and due to the hemodynamic stability, inotropic agents were not necessary. At the end of the procedure, the patient was extubated, presenting $\mathrm{SpO}_{2}$ 95\%, which remained around $85 \%$ in the immediate postoperative period, when the Blalock was operational. On the day of the hospital discharge, the patient presented $\mathrm{Hb}$ $15.9{\mathrm{~g} . \mathrm{dL}^{-1}}^{-1}$ and $\mathrm{Ht} 49 \%$. In the late postoperative period (one year after the surgery) the patient remained stable performing household chores with $\mathrm{SpO}_{2} 83 \%$.

\section{DISCUSSION}

Affecting approximately eight in every 1,000 live births ${ }^{3}$, congenital cardiac defects are the most common human congenital deformity. Patients with single ventricle with left ventricular morphology and rudimentary anterior chamber represent $0.7 \%$ of all congenital cardiopathies ${ }^{1}$. Rare patients reach adulthood without palliative or corrective surgery, unless they also present pulmonary stenosis or mild to moderate pulmonary hypertension ${ }^{2}$, since those factors can regulate pulmonary blood flow, allowing extended survival. The main causes of death are arrhythmias (atrial fibrillation) and congestive heart failure ${ }^{4}$.

In the present case, third degree AV block was secondary to the natural evolution of the disease, because in this type of cardiopathy the region of the cardiac valves and the region of the atrioventricular node are commonly affected, leading to the late development of third degree $A B$ block. Although this patient presented pulmonary stenosis, she developed pulmonary hypertension $(\mathrm{PH})$, probably due to in situ thrombosis or hypoplasia of branches of the pulmonary tree. However, $\mathrm{PH}$ was not severe, and a low pulmonary blood flow predominated in this patient, since she presented cyanosis and severe hypoxemia. Therefore, the modified BlalockTausig procedure was performed, because it was necessary to increase the pulmonary blood flow to improve $\mathrm{SpO}_{2}$, which was reduced due to a severe pulmonary stenosis. Initially, we thought of performing the surgical repair of Glenn (superior vena cava-pulmonary artery anastomosis); however, this technique should not be used in patients with pulmonary artery pressure greater than $15 \mathrm{mmHg}$, and this patient presented pulmonary artery pressure of $30 \mathrm{mmHg}$.

The physiological response of patients with single ventricle physiology to common interventions such as supplementary oxygen, mechanical ventilation, and vasoactive drugs is different than that of other patients ${ }^{5,6}$. With univentricular 
anatomy, circulations work in parallel, and both pulmonary and systemic circulations contain a mixture of oxygenated and non-oxygenated blood. Arterial oxygen saturations between $70 \%$ and $80 \%$ are physiologic for those patients; more elevated saturations, obtained by using supplementary methods, are deleterious for their physiology. Therefore, anesthetic handling of patients with parallel circulations demands deep understanding of the physiopathology of the disease, as well as individualization of the anesthetic technique. In complex congenital cardiopathies, the choice of anesthetic drugs is not as important as the knowledge and adequate handling of hemodynamic parameters ${ }^{6}$. Successful management of those patients usually demands maintenance of $\mathrm{SpO}_{2}$ around $75 \%$, and $\mathrm{SvO}_{2}$ around $50 \%$, in an attempt to maintain a balance between both circulations. Monitoring the $\mathrm{SvO}_{2}$ seems to be more adequate in those patients, because provides the level of $\mathrm{O}_{2}$ supplied to tissues, and some authors have indicated that it should be done continuously in the superior vena cava ${ }^{7}$. The $\mathrm{P}_{\mathrm{ET}} \mathrm{CO}_{2}$ in patients with low pulmonary blood flow loses its sensitivity as an indicator of the arterial pressure of $\mathrm{CO}_{2}\left(\mathrm{PaCO}_{2}\right)$ because, in those cases, the dead space is increased, which increases the $\mathrm{Pa}-\mathrm{P}_{\mathrm{ET}} \mathrm{CO}_{2}$ gradient. The main objective of anesthesia is to maintain the relationship between pulmonary and systemic output close to one. In parallel circulations, an excess of pulmonary blood flow decreases systemic blood flow, leading to a reduction in cardiac output, lactic acidosis, and myocardial dysfunction ${ }^{8}$. On the other hand, low pulmonary blood flow leads to severe hypoxemia, compromising the life of the patient. Thus, the management of those patients is based, mainly, on adequate ventilation. High $\mathrm{FiO}_{2}$, hypocapnia, and maneuvers that decrease pulmonary vascular pressure should be avoided, because they generate pulmonary vasodilation with high pulmonary blood flow, decreasing systemic blood flow. But hypoxemia and hypercapnia should also be avoided because they cause pulmonary vasoconstriction, shunting blood to the systemic circulation. Usually, a $\mathrm{FiO}_{2}$ of 0.5 mixed with room air is used, although some cases of patients with increased pulmonary blood flow require the addition of $\mathrm{CO}_{2}$ to the ventilating system to control pulmonary vasodilation ${ }^{9}$. For a long time, anesthesiologists used $\mathrm{SpO}_{2}$ as a guide in those cases. Nowadays, it is known that both $\mathrm{SpO}_{2}$ and hemodynamic parameters, such as BP and HR, for intraoperative monitoring of those patients are supplanted by biologic markers, like $\mathrm{SvO}_{2}$ (saturation of mixed venous blood) and lactate levels ${ }^{10,11}$. Saturation of mixed venous blood should be maintained around $50 \%$, and the tendency of lactate levels to increase or decrease is more important than absolute levels.

Early extubation can be done, as long as the patient is breathing spontaneously and is not at risk of retaining $\mathrm{CO}_{2}$; it can also be advantageous because it improves hemodynamics. However, many adults with congenital cardiopathies have altered pulmonary function, and this can be relevant when deciding for the early extubation of the patient.

\section{REFERÊNCIAS - REFERENCES}

01. Restaino G, Dirksen MS, de Roos A - Long-term survival in a case of unoperated single ventricle. Int $\mathrm{J}$ Cardiovasc Imaging, 2004;20:221-225.

02. Ammash NM, Warnes CA - Survival in adulthood of patients with unoperated single ventricle. Am J Cardiol, 1996;77:542-544.

03. Latin-Hermoso MR - Pediatric cardiology for the primary care pediatrician. Indian J Pediatr, 2005;72:513- 518.

04. Cabrera A, Fernández J, Alcibar $\mathrm{J}$ et al. - Ventrículo único de morfologia izquierda corregido a los 49 años com buena evolución. Rev Esp Cardiol, 2000;53:1140-1143.

05. Nelson DP, Schwartz SM, Chang AC - Neonatal physiology of the functionally univentricular heart. Cardiol Young, 2004; 14(suppl 1):52- 60.

06. Heggie J, Poirer N, Williams W et al. — Anesthetic considerations for the adult cardiac surgery patients with congenital heart disease. Semin Cardiothorac Vasc Anesth, 2003;7:141-153.

07. Tweddell JS, Hoffman GM, Mussatto KA et al. - Improved survival of patients undergoing palliation of hypoplasic left heart syndrome: lessons learned from 115 consecutive patients. Circulation, 2002;106:182-189.

08. Jobes DR, Nicolson SC, Steven JM et al. - Carbon dioxide prevents pulmonary over circulation in hipoplastic left heart syndrome. Ann Thorac Surg, 1992;54:150-151.

09. Keidan I, Mishaly D, Berkenstadt $\mathrm{H}$ et al. - Combining low inspired oxygen and carbon dioxide during mechanical ventilation for the Norwood procedure. Paediatric Anaesth, 2003;13: 58-62.

10. Hoffman GM, Tweddell JS, Ghanayem NS et al. - Alteration of the critical arteriovenous oxygen saturation relationship by sustained afterload reduction after the Norwood procedure. $J$ Thorac Cardiovasc Surg, 2004;127:738-745.

11. Hoffman GM, Ghanayem NS, Kampine JM et al. - Venous saturation and the anaerobic threshold in neonates after the Norwood procedure for hypoplastic left heart syndrome. Ann Thorac Surg, 2000;70:1515-1521.

\section{RESUMEN}

Lorentz MN, Soares RR, Ribeiro CVA, Valadares FW - Anestesia para Corrección Quirúrgica de Blalock-Taussig e Implante de Marcapaso en Adulto Portador de Ventrículo Único. Relato de Caso.

JUSTIFICATIVA Y OBJETIVOS: El ventrículo único es una cardiopatía compleja, rara y grave sin posibilidad de tratamiento quirúrgico curativo, asociada a una alta mortalidad durante la primera infancia. El objetivo de este artículo fue el de describir un caso raro de paciente adulto con ventrículo único no operado que se internó para la realización de valvoplastia pulmonar vía hemodinámica y que terminó siendo sometido a la cirugía de BlalockTaussig modificado e implante de marcapaso epicárdico. Tuvo como objetivo complementario destacar las particularidades anestésicas del paciente adulto portador de cardiopatía congénita no corregida.

RELATO DEL CASO: Paciente de 34 años, $60 \mathrm{~kg}$, portadora de cardiopatía congénita compleja tipo ventrículo único, estenosis infundíbulo valvar pulmonar importante e hipertensión pulmonar moderada. Admitida en el hospital sin condiciones de corrección quirúrgica y con historial anterior de varias sangrías terapéuticas para tratamiento de policitemía. Se le internó debido al empeoramiento de la hipoxemia, un episodio de síncope y bloqueo atrio- 


\section{ANESTHESIA FOR BLALOCK-TAUSSIG SHUNT AND PACEMAKER PLACEMENT IN AN ADULT PATIENT \\ WITH UNIVENTRICULAR HEART. CASE REPORT}

ventricular total (BAVT) de inicio reciente. En el momento de su internación presentaba estabilidad hemodinámica, frecuencia cardíaca de $42 \mathrm{lpm}, \mathrm{SpO}_{2}$ de $73 \%$, cianosis central y de extremidades y presión arterial de $120 \times 70 \mathrm{mmHg}$. Fue propuesta la realización de cateterismo y valvoplastía pulmonar vía hemodinámica. Debido a la imposibilidad de la realización de esa técnica con éxito, fue indicada la realización de cirugía de Blalock-Taussig con implante de marcapaso. El procedimiento fue realizado al día siguiente sin intercurrencias y la paciente tuvo alta hospitalaria 7 días después del procedimiento quirúrgico con $\mathrm{SpO}_{2}$ de $85 \%$, hematócrito de $49 \%$ y mejoría de la disnea.

CONCLUSIONES: El éxito del procedimiento anestésico para la corrección quirúrgica de cardiopatía congénita compleja exige el conocimiento de la fisiopatología de la enfermedad, como también las particularidades inherentes a la técnica anestésica utilizada. 